Dear Author,

Please, note that changes made to the HTML content will be added to the article before publication, but are not reflected in this PDF.

Note also that this file should not be used for submitting corrections. 


\title{
Using remote sensing products to classify landscape. A multi-spatial
} resolution approach

\author{
Q1 Paula García-Llamasa,*, Leonor Calvo a, José Manuel Álvarez-Martínez ${ }^{\mathrm{b}}$, \\ Susana Suárez-Seoane ${ }^{a}$ \\ 5 Q2 a Biodiversity and Environmental Management Dpt., Faculty of Biological and Environmental Sciences, University of León, 24071 León, Spain \\ ${ }^{\mathrm{b}}$ Environmental Hydraulics Institute "IH Cantabria", C/Isabel Torres 15, Parque Científico y Tecnológico de Cantabria, 39011 Santander, Spain
}

\section{A R T I C L E I N F O}

Article history:

Received 17 November 2015

Received in revised form 11 March 2016

Accepted 18 March 2016

Available online $\mathrm{xxx}$

\section{Keywords:}

CORINE

Land cover

NDVI

NOAA

Uncertainty

\begin{abstract}
A B S T R A C T
The European Landscape Convention encourages the inventory and characterization of landscapes for environmental management and planning actions. Among the range of data sources available for landscape classification, remote sensing has substantial applicability, although difficulties might arise when available data are not at the spatial resolution of operational interest. We evaluated the applicability of two remote sensing products informing on land cover (the categorical CORINE map at $30 \mathrm{~m}$ resolution and the continuous NDVI spectral index at $1 \mathrm{~km}$ resolution) in landscape classification across a range of spatial resolutions ( $30 \mathrm{~m}, 90 \mathrm{~m}, 180 \mathrm{~m}, 1 \mathrm{~km}$ ), using the Cantabrian Mountains (NW Spain) as study case. Separate landscape classifications (using topography, urban influence and land cover as inputs) were accomplished, one per each land cover dataset and spatial resolution. Classification accuracy was estimated through confusion matrixes and uncertainty in terms of both membership probability and confusion indices. Regarding landscape classifications based on CORINE, both typology and number of landscape classes varied across spatial resolutions. Classification accuracy increased from $30 \mathrm{~m}$ (the original resolution of CORINE) to $90 \mathrm{~m}$, decreasing towards coarser resolutions. Uncertainty followed the opposite pattern. In the case of landscape classifications based on NDVI, the identified landscape patterns were geographically structured and showed little sensitivity to changes across spatial resolutions. Only the change from $1 \mathrm{~km}$ (the original resolution of NDVI) to $180 \mathrm{~m}$ improved classification accuracy. The value of confusion indices increased with resolution. We highlight the need for greater effort in selecting data sources at the suitable spatial resolution, matching regional peculiarities and minimizing error and uncertainty.
\end{abstract}

(c) 2016 Published by Elsevier B.V.

\section{Introduction}

Different policies have been developed in Europe aiming to regulate landscape conservation, such as the Pan-European Biological and Landscape Diversity Strategy (Council of Europe, 1996), the Action Plan for European Landscapes (ECNC, 1997) and the European Landscape Convention (Council of Europe, 2000). Specifically, the European Landscape Convention encourages Contracting Parties to identify and classify their landscapes for protection, management and planning. In this way, a wide range of initiatives has been implemented at continental, national and regional scales in Europe, attempting to accomplish this recommendation. Examples are the European Landscape Map (LANMAP2) (Mücher et al., 2010), the Spanish Landscape Atlas (Mata Olmo and Sanz Herráiz,

\footnotetext{
* Corresponding author.

E-mail addresses: pgarcl@unileon.es, paula.gllmas@gmail.com (P. García-Llamas).
}

2003) and the German Typology of Landscapes (Gharadjedaghi et al., 2004). However, despite efforts, the European Landscape Character Initiative (ELCAI) (Wascher, 2005) highlighted discrepancies in these landscape classifications in terms of methodology, data sources, spatial resolution and nomenclature (Mücher et al., 2010), which make them incompatible and largely incomparable (Van Eetvelde and Antrop, 2008). Thus, the development of consistent methodologies for landscape classification, able to identify with realism, basic spatial units for use in environmental applications at a large scale, is necessary to fulfil policy and operational requirements (Blasi et al., 2000).

Numerical landscape classifications allocate patches of territory with similar characteristics (e.g., geology, topography, hydrology, land cover, socio-economy) into homogeneous landscape units. Among all landscape components, land cover is probably the most relevant, as it represents the interface between natural conditions and human influences, both across space and time. There is a wide range of data sources that can be used to describe land cover in environmental applications (Tomaselli et al., 2013), mainly consisting 


\section{Biogeographic regions}

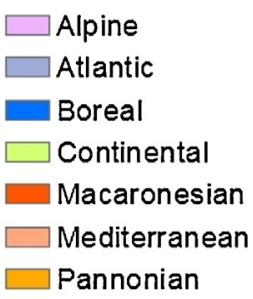

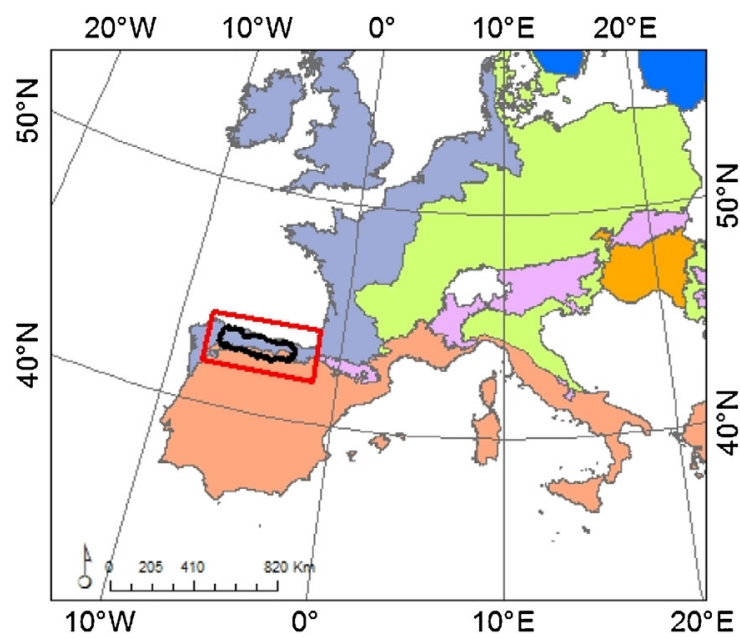

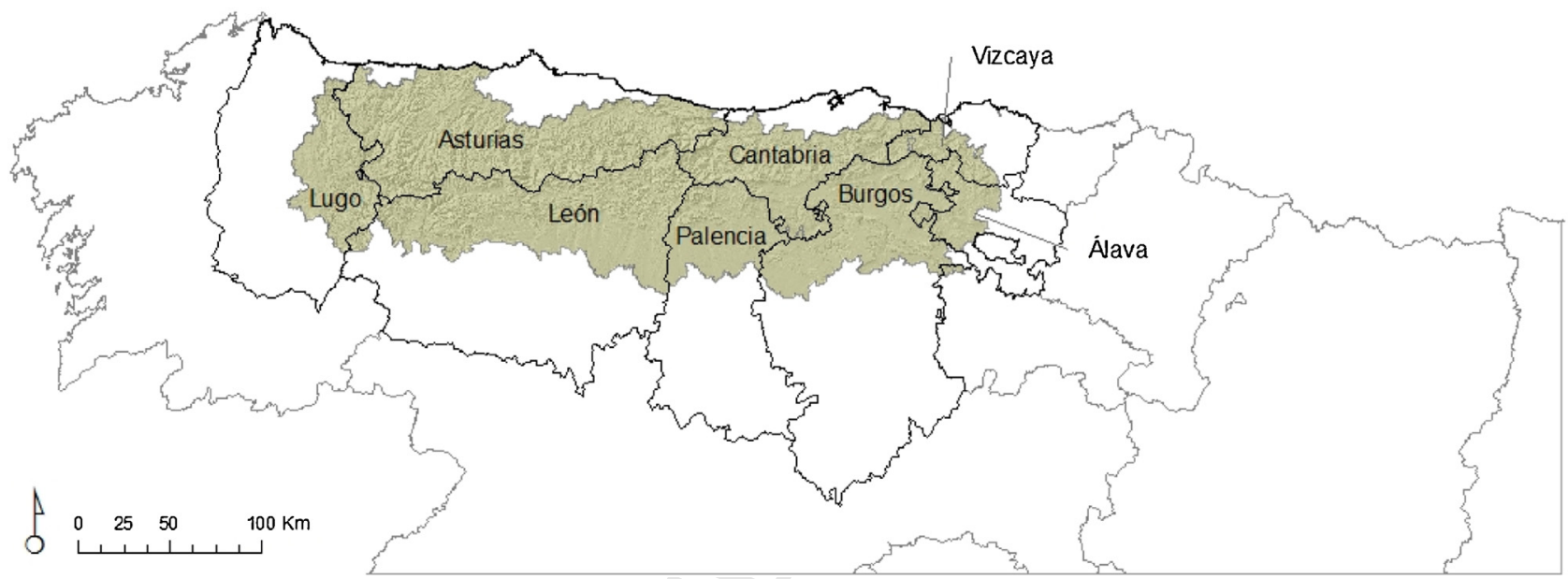

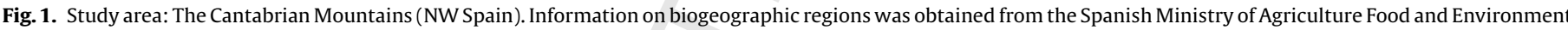
(http://www.magrama.gob.es/).

of categorical land cover maps derived from remote sensing data, as the International Geosphere-Biosphere Programme (Belward, 1996), the FAO land cover classification system (Di Gregorio and Jansen, 1998, 2004) or the CORINE Land Cover Programme (Bossard et al., 2000). Currently, most of these data can be found freely available, which can be useful for landscape managers, mainly when founding is limited (Nagendra et al., 2013). However, the matching between the spatial resolution of these products, with that at which landscape is intended to be characterized it is not always achievable (Garrigues et al., 2006; Shao and Wu, 2008). A lack of appropriate information can result in a gap between both, desired and hard-headed spatial resolution at which patterns and process can be represented (McCabe and Wood, 2006), generating spatial discrepancies between reality and analysis resolution.

Within the European context, CORINE is probably the data source most used to generate integrative landscape classifications in combination with other thematic data (Mücher et al., 2003, 2006, 2010; Van Eetvelde and Antrop, 2008; Cullotta and Barbera, 2011). However, despite its wide application, CORINE is a classification product derived from Landsat TM imagery that shows important problems of uncertainty (Regan et al., 2002), which can be propagated in subsequent analyses (Shao and Wu, 2008). Therefore, it should be carefully evaluated prior use to guaranty its applicability in management (Foody and Atkinson, 2002; Rae et al., 2007; Kennedy et al., 2009; Hou et al., 2013). This issue become especially relevant in mountain systems, where topographic and microclimatic patterns (Oke and Thompson, 2015) make ecological conditions to change substantially over relatively short distances, providing a wide range of environments and hence, a great diversity of habitats and species (Becker and Bugmann, 2001). Because of this environmental heterogeneity, classifying land cover in mountain areas is especially challenging due to the existence of mixed pixels that can mislead the final classifications (Álvarez-Martínez et al., 2010). Considering these constraints inherent to categorical maps, a good alternative could be the use of continuous variables as the spectral indices derived from remote sensing imagery (Suárez-Seoane et al., 2002; Morán-Ordóñez et al., 2012; ÁlvarezMartínez et al., 2015; Roces-Díaz et al., 2015). The spectral index most commonly used in environmental research is the Normalized Vegetation Index (NDVI) (Rouse et al., 1973; Tucker, 1979). This index has been related to functional attributes of ecosystems like aboveground net primary production (Paruelo et al., 2001), vegetation functional characteristics such as phenology or primary productivity (Gamon et al., 2013) and vegetation structure such as aboveground biomass (Zhu and Liu, 2014). Many authors have applied this index to produce categorical land cover maps which are then used in subsequent analysis (Muniaty and Ratshibvumo, 2010; Tchuenté et al., 2011; Pervez et al., 2014). Nevertheless, we found no studies using this product as a direct input in integrative landscape classifications. The reason could be that NDVI provides an indication of the "greenness" of vegetation but does not inform directly on land cover, which may hamper the interpretation of final maps (Wang and Tenhunen, 2004). 


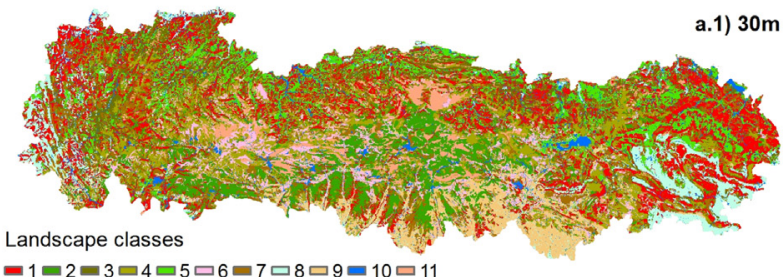

=1ロ2ே3ロ4ロ5ロ6ロ7ロ8ロ9ロ10ロ11

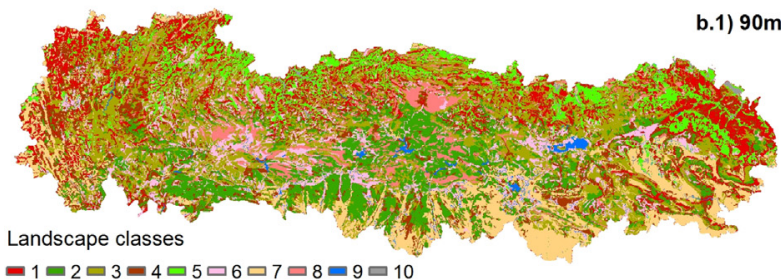

= 1 ロ 2 ロ $3=4 \square 5 \square 6 \square 7 \square 8=9 \square 10$

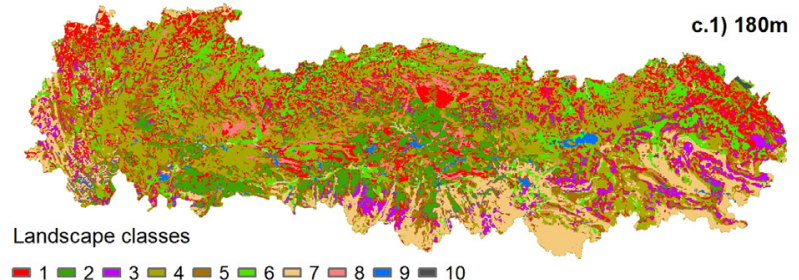

분 2 브 $3 \square 45 \square 6 \square 7 \square 8 \square 9=10$

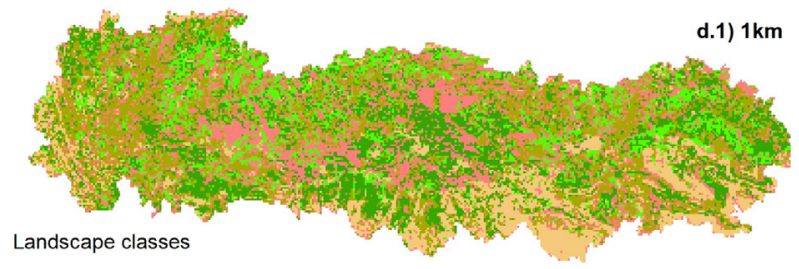

$\because 1 \square 2 \square 3 \square 4 \square 5$

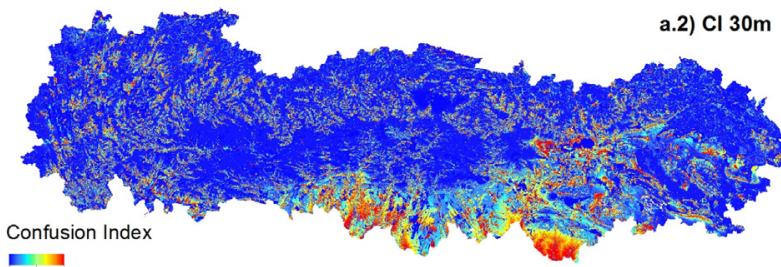

1000

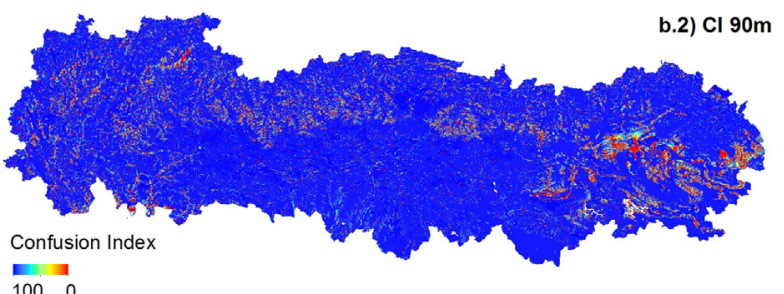

1000
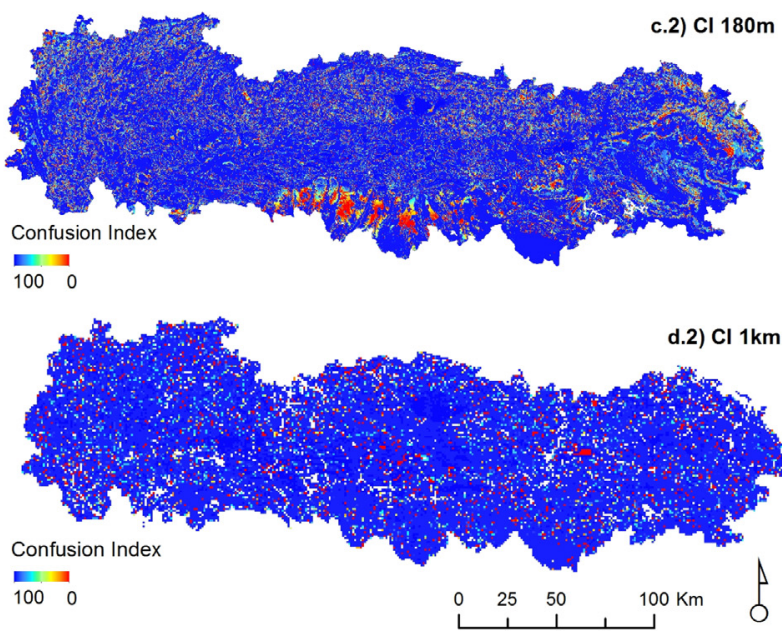

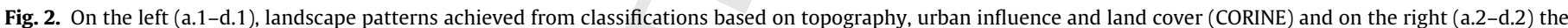

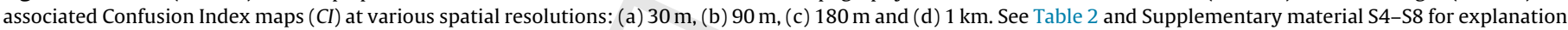
and statistical characterization of landscape classes.

This study aims to explore the applicability of two of the most readily available open remote sensing products accounting for land cover (the CORINE land cover classification from Landsat at $30 \mathrm{~m}$ resolution and the spectral index NDVI from NOAA-AVHRR at a $1 \mathrm{~km}$ ) for integrative landscape classification across spatial resolutions. In particular, we explore: (i) how classification typology and landscape pattern change across spatial resolution; (ii) how the error and uncertainty associated with data source, spatial resolution and landscape classification process could influence results in a complex mountain system.

\section{Material and methods}

\subsection{Study area}

The study area lies in the Cantabrian Mountains (northwest Spain) located at the transition between Eurosiberian and Mediterranean biogeographical regions (Rivas-Martínez, 1987)(Fig. 1). This is an area of $31,494 \mathrm{~km}^{2}$ with altitudes ranging from sea level to 2650 m.a.s.l. Average annual rainfall varies from 700 to $2400 \mathrm{~mm}$ and mean annual temperature from $4{ }^{\circ} \mathrm{C}$ to $22^{\circ} \mathrm{C}$. Landscape pattern is heterogeneous and is driven by climatic and topographic conditions, as well as human activities. Land cover types vary from crop fields (in lowlands) to natural vegetation (in mid-highlands), including heathlands scrublands and deciduous forests dominated by Fagus sylvatica, Betula pubescens, Quercus petraea and Quer- cus robur on northern slopes and Quercus pyrenaica and Quercus rotundifolia on southern slopes. In addition, plantations of Pinus pinaster, Pinus radiata and Eucalyptus globulus can be found in the study area, covering medium-to-low slopes previously occupied by shrubs and heathers. The Cantabrian Mountains have been widely recognized as a hot spot of biodiversity hosting a wide variety of ecosystems habitats and endemic species (Worboys et al., 2010; Álvarez-Martínez et al., 2011; Morán-Ordóñez et al., 2011).

\subsection{Input environmental variables: topography, urban influence and land cover}

We derived a set of environmental variables informing on topography, urban influence and land cover at four spatial resolutions ( $30 \mathrm{~m}, 90 \mathrm{~m}, 180 \mathrm{~m}$ and $1 \mathrm{~km}$ ) (Table 1 ). Pixel sizes of $30 \mathrm{~m}$ and $1 \mathrm{~km}$ correspond to the original resolution of the remote sensing data accounting for land cover, while $90 \mathrm{~m}$ and $180 \mathrm{~m}$ are intermediate resolutions chosen according to data availability on topography and urban influence.

Topographic variables consisted on elevation solar radiation and slope. They were calculated separately from four Digital Elevation Models (DEM) proximal to the above-mentioned spatial resolutions and obtained from the Spanish Geographic Institute (www.ign. es), and the U.S. Geological Survey (www.usgs.gov). Urban influence was estimated as the Euclidian distance to urban settlements, independently for the target spatial resolutions, using data from 
Table 1

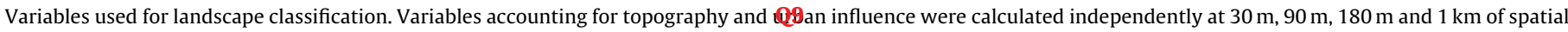

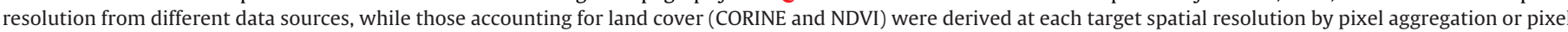
resampling from the original data source.

\begin{tabular}{|c|c|c|c|}
\hline Family & Code & Description & Original data set \\
\hline Topography & $\begin{array}{l}\text { DEM } \\
\text { SLO } \\
\text { SOLR }\end{array}$ & $\begin{array}{l}\text { Elevation (in meters) } \\
\text { Slope (in percentage) } \\
\text { Solar radiation }\left(\times 10^{6} \mathrm{~W} / \mathrm{h}\right)\end{array}$ & $\begin{array}{l}\text { Digital Elevation Models (DEM) at } \\
25 \mathrm{~m}, 90 \mathrm{~m}, 200 \mathrm{~m} \text { and } 1 \mathrm{~km} \text { of } \\
\text { spatial resolution }\end{array}$ \\
\hline Urban influence & $\mathrm{AC}$ & $\begin{array}{l}\text { Urban influence across the territory measured as Euclidian } \\
\text { distance to settlements (in meters) }\end{array}$ & $\begin{array}{l}\text { Vector layers at } 1: 25,000, \\
1: 100,000,1: 200,000 \text { and } \\
1: 500,000\end{array}$ \\
\hline Land cover (CORINE) & $\begin{array}{l}\text { INFRA } \\
\text { MIN } \\
\text { HERC } \\
\text { WOOC } \\
\text { PAS } \\
\text { FOR } \\
\text { TWOOD } \\
\text { SCRUB } \\
\text { SPAR } \\
\text { BARE } \\
\text { WET } \\
\text { WAT }\end{array}$ & $\begin{array}{l}\text { Human infrastructures (\%) } \\
\text { Mineral extraction sites (\%) } \\
\text { Herbaceous crop lands (\%) } \\
\text { Woody crop land coverage (\%) } \\
\text { Pasturelands (\%) } \\
\text { Forest coverage (\%) } \\
\text { Transitional woodland-shrublands (\%) } \\
\text { Mosaic of sclerophyllous-herbaceous vegetation (\%) } \\
\text { Sparsely vegetated areas (\%) } \\
\text { Bare areas (\%) } \\
\text { Wetlands (\%) } \\
\text { Water (\%) }\end{array}$ & $\begin{array}{l}\text { CORINE Land Cover } 2006 \text { at } 30 \mathrm{~m} \\
\text { spatial resolution }\end{array}$ \\
\hline Land cover (NDVI) & NDVI & $\begin{array}{l}\text { Annual average NDVI index (no units ranging from }-1 \text { to } \\
+1 \text { ) }\end{array}$ & $\begin{array}{l}\text { NDVI from NOAA-AVHRR at } \\
1 \text { km of spatial resolution for } \\
\text { years } 1983,1985,1990,1993 \\
\text { and } 1996\end{array}$ \\
\hline
\end{tabular}

the Spanish Geographic Institute (www.ign.es). Land cover variables were generated from two datasets: (i) the CORINE categorical map for the year 2006 at $30 \mathrm{~m}$ of spatial resolution; and (ii) a mean annual NDVI spectral index at $1 \mathrm{~km}$, derived from a temporal monthly series for years 1983, 1985, 1990, 1993, 1996 and 1999. The CORINE Land Cover classification (http://www.eea.europa.eu/ publications/COR0-landcover) comprises 44 land cover classes at the most detailed of the three available levels (Bossard et al., 2000). But, in the study area, only 38 out of the 44 classes were present. These classes were reclassified into 12 main categories with the purpose of simplifying the original dataset (see S1). With the aim of improving map reliability, the resulting product was merged with an extra dataset of rivers and infrastructures (roads, railways and settlements) downloaded from the Spanish Geographic Institute site (www.ign.es), at 1:200,000 spatial resolution. To account for the accuracy of this new CORINE map, we carried out a visual validation based on coetaneous orthophotographs (years 2006-2009, at 1:5000-1:10,000 spatial resolution) and field surveys (Bossard et al., 2000; Vogiatzakis et al., 2006; Kienast et al., 2009) on a dataset of 320 sampling points. We followed a stratified random sampling design by municipality and land cover class, being, therefore, the sampling size proportional to the extent of the municipalities and land cover classes. Accumulative adjustment curves were created to identify a representative number of points. The overall accuracy of the new CORINE was $82.5 \%$, ranging across land cover classes from 66.67 to $100 \%$ (S1). The map was resampled at the four target spatial resolutions by using the majority rule, which is one of the most common approaches to aggregate categorical data $(\mathrm{Wu}$, 2004). The 12 classes of the new CORINE were subsequently turned into independent continuous variables by calculating the proportion covered by class at each pixel of $30 \mathrm{~m}, 90 \mathrm{~m}, 180 \mathrm{~m}$ and $1 \mathrm{~km}$. NDVI original data were captured by an Advanced Very High Resolution Radiometer (AVHRR) on board the NOAA satellite, received by the Natural Environment Research Council Satellite Receiving Station at Dundee (UK) and processed by the Remote Sensing Group at the Plymouth Marine Laboratory (UK). See Suárez-Seoane et al. (2002) and Osborne et al. (2007) for technical details on these data. The original NDVI dataset had a pixel size of $1 \mathrm{~km}$ and was resam- pled to the above-mentioned spatial resolutions using a nearest algorithm.

Prior to landscape classification analysis we standardized all continuous environmental variables (Table 1 ) to set them to the same range, by applying the Eq. (1)

$Z=\frac{(X-\text { oldmin }) \times(\text { newmax }- \text { newmin })}{(\text { oldmax }- \text { oldmin })}+$ newmin

where $Z$ is the output raster with new data ranges, $X$ is the input raster, oldmin is the minimum value of the input raster, oldmax is the maximum value of the input raster, newmin is the desired minimum value for the output raster and newmax is the desired maximum value for the output raster.

\subsection{Landscape classification across spatial resolutions: accuracy and uncertainty}

We accomplished eight landscape classification analyses for the Cantabrian Mountains based on topography, urban influence and land cover (Table 1). We carried out an independent analysis for each land cover dataset (CORINE and NDVI) and spatial resolution ( $30 \mathrm{~m}, 90 \mathrm{~m}, 180 \mathrm{~m}$ and $1 \mathrm{~km}$ ). First, we ran a Principal Components Analysis (PCA) over the standardized variables. We then clustered similar pixels into comprehensive landscape classes, by applying an unsupervised classification with the maximum likelihood algorithm on the PCA components (Schowengerdt, 1983; Conese and Maselli, 1992). A similar methodological approach to classify landscape has been used by other authors such as Owen et al. (2006), Morán-Ordóñez et al. (2011) and Gan et al. (2012).

The error of each landscape classification was measured in terms of accuracy, which was quantified by using thematic information related to topography, urban influence and land cover and orthophotographs (years 2006-2009, scale 1:5000-1:10,000), (Bossard et al., 2000; Vogiatzakis et al., 2006; Kienast et al., 2009). Each landscape map was evaluated using independent datasets of 300 points each, that were collected across the study area by applying a random sampling design stratified by class. This sampling size guaranteed an adequate representativeness of all landscape classes and was defined according to accumulative adjustment curves (S2), which allowed for identifying the appropriated number of valida- 

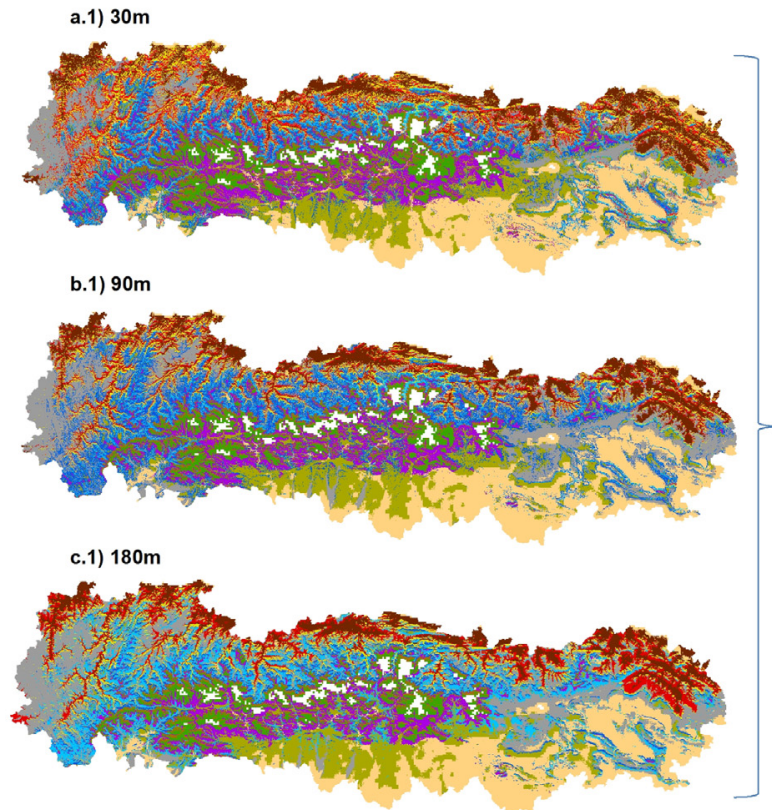

d.1) $1 \mathrm{~km}$

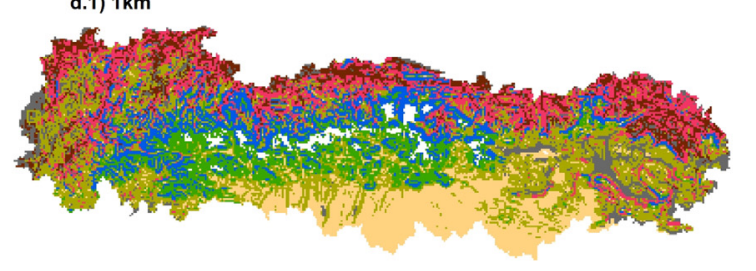

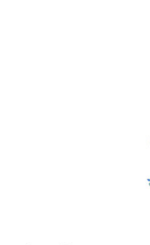

Landscape classes

$\square 1$

$\square 2$

$\square 4$

$\square 5$

$\square 6$

$\square 7$

붕 8

$\square 10$

- 11
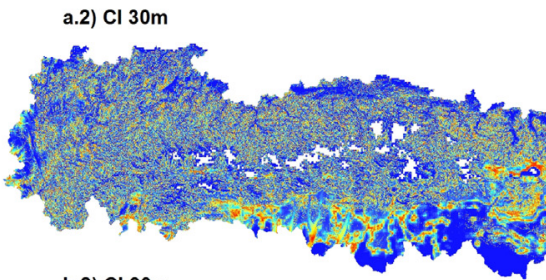

Confusion Index 1000
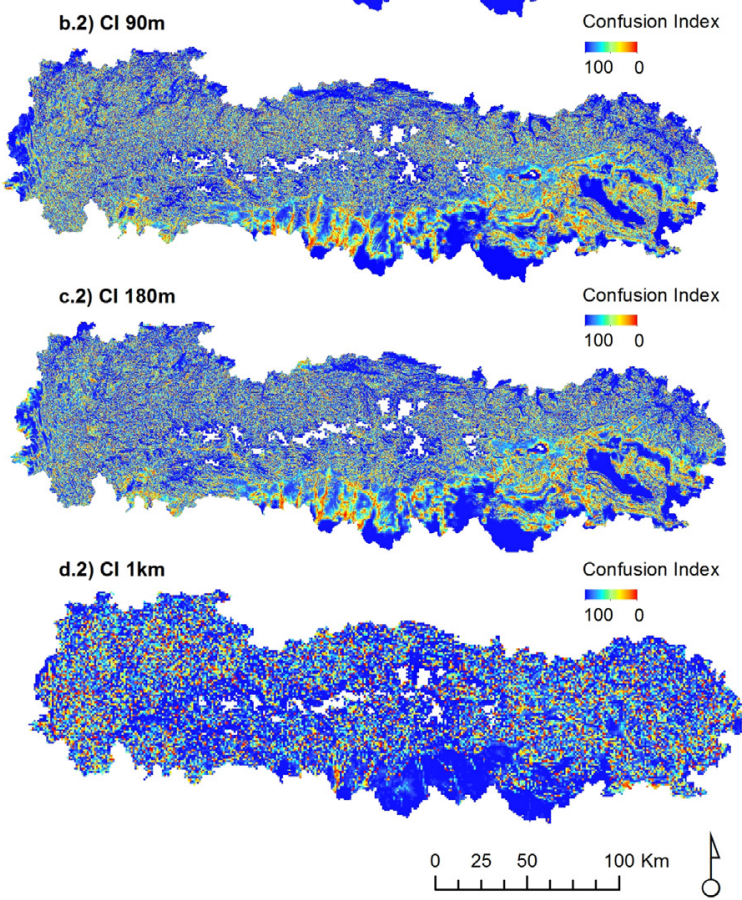

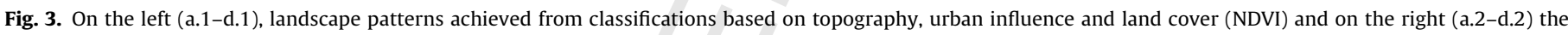

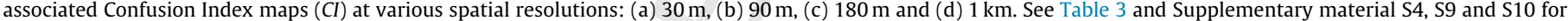
explanation and statistical characterization of landscape classes.

tion points for each landscape classification. We avoided the use of a unique testing dataset for validating all landscape classifications because any selection of points would be biased towards a particular spatial resolution and/or original data source. We created a confusion matrix for each classification obtaining the overall percentage of points correctly allocated to landscape classes and the user's and producer's accuracy per class.

The maximum likelihood rule allocates pixels to classes according to their maximum membership probability. However, a pixel may have a certain degree of similarity to more than one class and therefore, almost equal probability of membership to all of them. In these cases, pixel allocation can be erroneous (Lewis et al., 2000). This problem is considered a main source of uncertainty in classification processes (Foody, 2000; Owen et al., 2006). To assess the uncertainty derived from erroneous allocations for each pixel in each class, we applied the methodology of Álvarez-Martínez et al. (2010), which is based on fuzzy membership to all landscape classifications. We distinguished between two aspects of classification uncertainty: (i) the uncertainty of pixel allocation to a particular class (probability of membership); and (ii) the confusion associated with the classification of a pixel among classes accepting that one pixel can belong to more than one class (expressed by the Confusion Index). Membership is a measure of the similarity between the characteristics of a particular pixel and the representative vector of a class (Bollinger and Mladenoff, 2005). It was estimated by calculating the Euclidian distance between each pixel value and the characteristic vector of the class. A large Euclidian distance indicates large differences between the pixel attributes and the typical case of the target class. In this case, membership probability will be low and uncertainty high. Membership values were then used to create a Confusion Index (CI) map. We calculated the difference between the highest membership probability to a class and the second-largest membership probability for the same pixel to another class. When a class dominates, differences between the highest and the second highest class membership probability is large. In this situation, $C I$ tends towards " 1 " and there is little confusion in class allocation. Otherwise, when membership is similar to more than one class, confusion among classes is high and $C I$ tends towards " 0 ".

All analyses were done in ArcGIS 10.2 (Esri. 2014).

\section{Results}

\subsection{Landscape patterns and classification typologies}

Landscape patterns derived from landscape classifications based on CORINE, as a proxy of land cover, showed a weak geographic structure (Fig. 2, cases a.1-d.1). The number of landscape classes decreased when pixel size became coarser: eleven classes at $30 \mathrm{~m}$, ten at $90 \mathrm{~m}$ and $180 \mathrm{~m}$ and five at a $1 \mathrm{~km}$ spatial resolution. The typology of the classes also varied among these spatial resolutions.

When using NDVI as land cover data source in landscape classification, the resulting landscape mosaic was strongly structured across a gradient North to South, being this geographic pattern consistent across spatial resolutions (Fig. 3, cases a.1-d.1, S3). Classifications led to the identification of 11 classes at $30 \mathrm{~m}, 90 \mathrm{~m}$ and $180 \mathrm{~m}$ and 7 at $1 \mathrm{~km}$ pixel size. Thus, classification typology showed little sensitivity to changes across spatial resolutions. 
Table 2

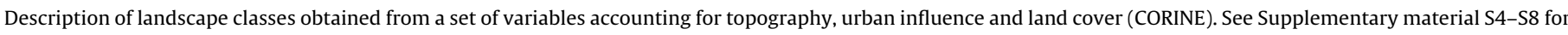
further explanations.

\begin{tabular}{|c|c|}
\hline Class & Description \\
\hline \multicolumn{2}{|c|}{$30 \mathrm{~m}$ resolution } \\
\hline 1 & Forests covering coastal and middle-mountain areas under 1000 m.a.s.l. \\
\hline 2 & Forests covering central mountains and piedmont areas at altitudes above 1000 m.a.s.l. \\
\hline 3 & $\begin{array}{l}\text { Transitional to woodlands with relatively low urban influence covering mainly Atlantic and Sub-Atlantic mountains, in areas } \\
\text { with mid-low altitudes ( } 600 \text { m.a.s.l.) }\end{array}$ \\
\hline 4 & Transitional woodlands from central and southern areas of the Cantabrian Mountains, with altitudes from 1500 to 900 m.a.s.l. \\
\hline 5 & Pastures in mid-low (under 800 m.a.s.l.) Atlantic mountains and coastal areas \\
\hline 6 & $\begin{array}{l}\text { Pastures covering bottom valleys and hillsides of central Cantabrian Mountains, with altitudes ranging from } 1500 \text { to } \\
1000 \text { m.a.s.l. }\end{array}$ \\
\hline 7 & Shrub-herbaceous associations lying at altitudes between 1200-500 m.a.s.l. \\
\hline 8 & Croplands from depressions and coastal areas at low altitude close to settlements \\
\hline 9 & $\begin{array}{l}\text { Croplands (non-irrigated arable lands) from paramos and countrysides under } 1000 \text { m.a.s.l., being the closest class to } \\
\text { settlements }\end{array}$ \\
\hline 10 & Water surfaces and artificial surfaces in areas of wide altitudinal ranges \\
\hline 11 & Rocks and areas with little or no vegetation covering wide altitudinal ranges \\
\hline \multicolumn{2}{|c|}{$90 \mathrm{~m}$ resolution } \\
\hline 1 & $\begin{array}{l}\text { Forests covering coastal and middle-mountain areas mainly from Atlantic and Sub-Atlantic mountains, under } 850 \text { m.a.s.l. and } \\
\text { relatively close to settlements }\end{array}$ \\
\hline 2 & $\begin{array}{l}\text { Forests covering central mountains and piedmont areas with low urban influence at altitudes above } 900 \text { m.a.s.l., with low } \\
\text { urban influence }\end{array}$ \\
\hline 3 & Transitional to woodland areas across a wide altitudinal range \\
\hline 4 & Shrub-herbaceous associations lying at altitudes between $1200-500$ m.a.s.l. \\
\hline 5 & Pastures in mid-low Atlantic mountains and coastal areas under 600 m.a.s.l. \\
\hline 6 & Pastures covering bottom valleys and hillsides of central Cantabrian Mountains with altitudes ranging from 1400 to 700 m.a.s.l. \\
\hline 7 & Croplands from coastal areas depressions paramos and country sides under 1000 m.a.s.l. \\
\hline 8 & Rocks and areas with little or no vegetation covering a wide altitudinal range \\
\hline 9 & Water surfaces covering a wide altitudinal range \\
\hline 10 & Settlements roads railways or mines at very low altitude \\
\hline \multicolumn{2}{|c|}{$180 \mathrm{~m}$ resolution } \\
\hline 1 & $\begin{array}{l}\text { Areas with little vegetation and forests, covering coastal and middle-mountain areas mainly from Atlantic and Sub-Atlantic } \\
\text { mountains, situated at a wide altitude range }\end{array}$ \\
\hline 2 & Forests covering high central mountains and piedmont areas with relative urban influence, at altitudes above 1000 m.a.s.l. \\
\hline 3 & Forests covering depressions paramos and countrysides in altitudes under 1000 m.a.s.l. \\
\hline 4 & Transitional to woodland areas at wide altitudinal ranges and relative high urban influence \\
\hline 5 & Shrub-herbaceous associations lying at altitudes between 1200-500 m.a.s.l. \\
\hline 6 & Pastures covering areas with wide altitudinal and solar radiation range at middle to slight slope \\
\hline 7 & Croplands from coastal areas depressions paramos and country sides under 1000 m.a.s.l. \\
\hline 8 & Rocks and areas with no vegetation covering a wide altitudinal range \\
\hline 9 & Water surfaces covering a wide altitudinal range \\
\hline 10 & Settlements roads railways or mines at very low altitude \\
\hline \multicolumn{2}{|c|}{$1 \mathrm{~km}$ resolution } \\
\hline 1 & Forests lying at wide altitude range \\
\hline 2 & Transitional woodland and shrub areas with fairly urban influence at wide altitudinal ranges \\
\hline 3 & Pastures covering areas with relative urban influence and wide altitudinal \\
\hline 4 & Croplands from coastal areas depressions paramos and countryside along with water surfaces under 1000 m.a.s.l. \\
\hline 5 & Rocks areas with no vegetation and artificial surfaces covering a wide altitudinal range \\
\hline
\end{tabular}

See Tables 2 and 3 and Supplementary material S4-S10 for a detailed characterization of landscape classes.

\subsection{Landscape classification accuracy}

Landscape classifications based in CORINE land cover data reached an overall accuracy higher than $80 \%$ at all spatial resolutions, with user's and producer's accuracy per class higher than $50 \%$ and $68 \%$, respectively (Table 4 ). When the spatial resolution of analysis decreased from $30 \mathrm{~m}$ (the original pixel size of CORINE) to $90 \mathrm{~m}$, classification accuracy improved. However, when the spatial resolution was coarser than $90 \mathrm{~m}$, classification accuracy diminished.

Landscape classifications based on NDVI grasped an overall accuracy higher than $79 \%$ at all spatial resolutions, with user's and producer's accuracy per class higher than 57\% and 65\% respectively (Table 5). When the spatial resolution of analysis increased from $1 \mathrm{~km}$ (the original pixel size of NDVI) to $180 \mathrm{~m}$, classification accuracy improved. Nevertheless, when the spatial resolution was higher than this, classification accuracy decreased.

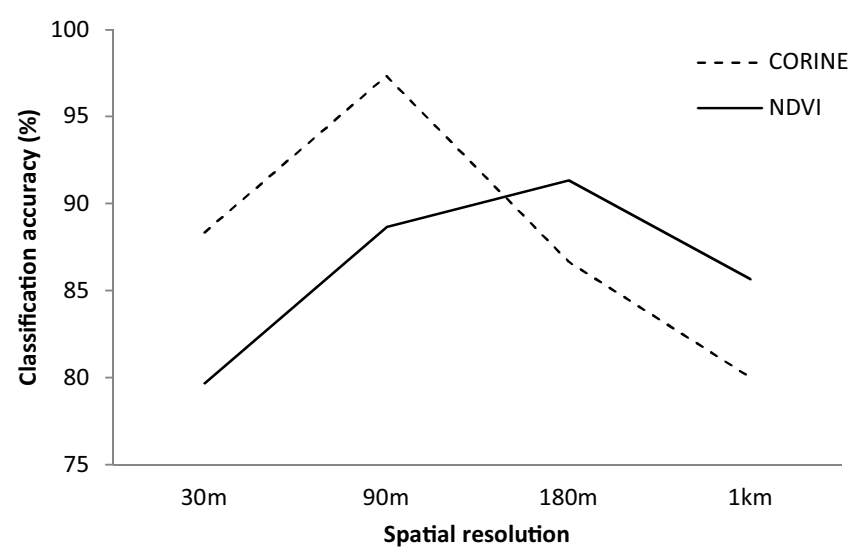

Fig. 4. Landscape classification accuracy across spatial resolutions.

In none of the cases, classification accuracy was maximal at the original spatial resolution of NDVI and CORINE land cover datasets (i.e., $30 \mathrm{~m}$ and $1 \mathrm{~km}$ pixel size respectively) (Fig. 4). 
Table 3

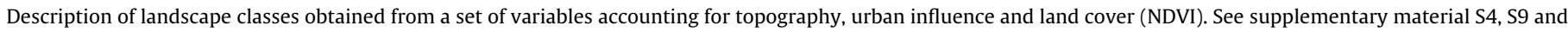
S10 for further explanations.

\begin{tabular}{|c|c|}
\hline Class & Description \\
\hline \multicolumn{2}{|c|}{$30 \mathrm{~m} 90 \mathrm{~m}$ and $180 \mathrm{~m}$ resolution } \\
\hline 1 & $\begin{array}{l}\text { Sea inlets, coastal plains and sub-coastal valleys, located at the lowest altitude dominated by a mosaic of crops and pastures } \\
\text { with a high presence of natural vegetation }\end{array}$ \\
\hline 2 & $\begin{array}{l}\text { Hillsides under a.s.l. with a northern exposure and mid-high slope from Atlantic and Sub-Atlantic mountains, covered by a } \\
\text { mosaic of scrubs and forests mixed with pastures in coastal areas }\end{array}$ \\
\hline 3 & $\begin{array}{l}\text { Hillsides under } 650 \text { m.a.s.l., with a southern exposure and mid-high slope from Atlantic and Sub-Atlantic mountains, covering } \\
\text { by a mosaic of scrubs and forests mixed with pastures in coastal areas }\end{array}$ \\
\hline 4 & $\begin{array}{l}\text { Complex cultivation patterns (crops and pasture mosaic) with high presence of natural vegetation in areas, with moderate } \\
\text { slope at low altitude }\end{array}$ \\
\hline 5 & Woody and scrub vegetation with rock formations covering northern faces of the upper part of Atlantic mountains \\
\hline 6 & Woody and scrub vegetation with rock formations covering southern faces of the upper part of Atlantic mountains \\
\hline 7 & $\begin{array}{l}\text { Hillsides in the central area of the Cantabrian Mountains above } 1400 \text { m.a.s.l., with northern exposure and dominated by rock } \\
\text { formations with moors and high mountain forests }\end{array}$ \\
\hline 8 & $\begin{array}{l}\text { Hillsides and mid-hillsides under } 1400 \text { m.a.s.l. and valleys above } 1300 \text { m.a.s.l. in the central area of the Cantabrian Mountains, } \\
\text { with sun-facing exposure and dominated by broadleaf forest mixed with pastures and heathlands }\end{array}$ \\
\hline 9 & $\begin{array}{l}\text { Peaks and mountainsides above } 1400 \text { m.a.s.l. with southern western and eastern exposures in the central areas of the } \\
\text { Cantabrian Mountains and dominated by rock formations pastures moors heathlands and forests }\end{array}$ \\
\hline 10 & $\begin{array}{l}\text { Valley bottoms from high central areas of the Cantabrian Mountains extending to piedmont areas, dominated by pastures in } \\
\text { the valley bottoms and mosaics of forests scrubs and crops in piedmont areas }\end{array}$ \\
\hline 11 & $\begin{array}{l}\text { Paramos, countryside and depressions at low altitude, with moderate to high solar radiation rates and dominated by intensive } \\
\text { crops }\end{array}$ \\
\hline \multicolumn{2}{|c|}{$1 \mathrm{~km}$ resolution } \\
\hline 1 & $\begin{array}{l}\text { Sea inlets, coastal plains and sub-coastal valleys, located at the lowest altitude and dominated by a mosaic of crops and } \\
\text { pastures with a high presence of natural vegetation. }\end{array}$ \\
\hline 2 & Coastal hills under $800 \mathrm{~m}$, with moderate solar radiation and slope dominated by pastures with natural vegetation areas \\
\hline 3 & $\begin{array}{l}\text { Depressions mainly covered by complex cultivation patterns in areas with an average altitude of } 600 \text { m. } 600 \text { m.a.s.l., slight } \\
\text { slope and moderate to high solar radiation rates }\end{array}$ \\
\hline 4 & $\begin{array}{l}\text { Middle mountain areas under } 1400 \text { m.a.s.l. with moderate solar radiation and slope rates, dominated by forests scrub and } \\
\text { transitional woodland formations }\end{array}$ \\
\hline 5 & $\begin{array}{l}\text { High central mountains with an average altitude around } 1400 \text { m.a.s.l. with moderate slope, high solar radiation rates and } \\
\text { dominated by forests, scrubs and bare and semi-bared areas }\end{array}$ \\
\hline 6 & $\begin{array}{l}\text { Valley bottoms from high central areas of the Cantabrian Mountains extending to piedmont areas and Sub-Atlantic } \\
\text { mountains, with gentle slope and dominated by pastures in valley bottoms and forest formations accompanied by scrubs and } \\
\text { mosaic of crops fields in piedmont areas }\end{array}$ \\
\hline 7 & Paramos, countryside and depressions with moderate to high solar radiation rates and dominated by crops \\
\hline
\end{tabular}

\subsection{Landscape classification uncertainty}

Regarding CORINE-based landscape classifications, membership probability was dependent on the spatial resolution, as Euclidean distances between pixel attributes and the characteristic vector of the class decreased when pixel size increased from $30 \mathrm{~m}$ to $90 \mathrm{~m}$. However, they consistently increased when pixel size became coarser than $90 \mathrm{~m}$ (Table 4). The higher differences in Euclidean distances among classes were detected at $30 \mathrm{~m}$ resolution. Additionally, the confusion associated with the classification of a pixel among classes was also dependent on the spatial resolution of analysis (Fig. 2; cases a.2-d.2). Classes were represented with lower confusion at $1 \mathrm{~km}$ and $90 \mathrm{~m}$ pixel size. In contrast, the highest confusion was found at the original $(30 \mathrm{~m})$ and intermediate $(180 \mathrm{~m})$ spatial resolutions.

Considering NDVI-based classifications, membership probability almost did not vary across spatial resolutions (Table 5). There were no clear differences in Euclidean distances among classes at any spatial resolution. The use of NDVI in landscape classification produced high confusion among classes ( $C I$ values closer to 0 ) (Fig. 3; cases a.2-d.2). We did not find consistent differences in $\mathrm{CI}$ values among $30 \mathrm{~m}, 90 \mathrm{~m}$ and $180 \mathrm{~m}$ spatial resolutions, with CI increasing only at $1 \mathrm{~km}$ grain size.

\section{Discussion}

We have demonstrated the value of two of the most readily available remote sensing products accounting for land cover (the CORINE land cover map from Landsat TM at a $30 \mathrm{~m}$ pixel size and the spectral index NDVI from NOAA-AVHRR at a $1 \mathrm{~km}$ ) in land- scape classification at different spatial resolutions. The consistency of classifications across spatial resolutions is a key concern for landscape managers, because information achieved at a particular level should be reproducible ideally at other decision-making levels (Rocchini and Ricotta, 2007). Nevertheless, although this consistency might be desirable, caution is urged, as landscape is hierarchically structured and most ecological processes and patterns are scale-dependent (Schröder and Seppelt, 2006). Thus, ecological patterns and processes should be evaluated only when the spatial resolution of available data matches the target phenomenon; otherwise, we could miss it (Jelinski and Wu, 1996). Information that can be relevant at low hierarchical levels might become irrelevant over a given threshold of aggregation or vice versa (Karl and Maurer, 2010). In this sense, our multi-spatial resolution approach showed how the perception of landscape patterns can be affected by using input data collected at a spatial resolution different to that of the landscape classification analyses.

When using CORINE $30 \mathrm{~m}$ as an input in landscape classification analysis, the number and typology of classes differed across spatial resolutions. From a practical perspective, this fact is relevant as it could limit the implementation of this approach for management purposes (Rocchini and Ricotta, 2007). It is well known that thematic resolution (number and typology of classes) of landscape maps may constrain results of further landscape analyses (SuárezSeoane and Baudry, 2002; Gimona et al., 2009), leading to different ecological findings. Nevertheless, the use of CORINE in landscape classification was advantageous, since landscape classes were easily characterized and interpreted, as CORINE account directly for land cover. Regarding the error and uncertainty of CORINE-based classifications, we found the original data to be a main source of error for further classification process, being the generaliza- 
Table 4

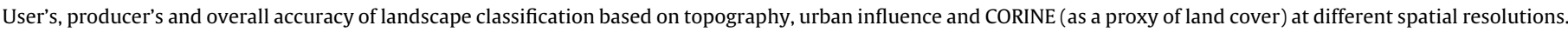
The table also shows the probability of membership (i.e., the Euclidian distance from pixel values to the characteristic vector of each class; mean \pm SD).

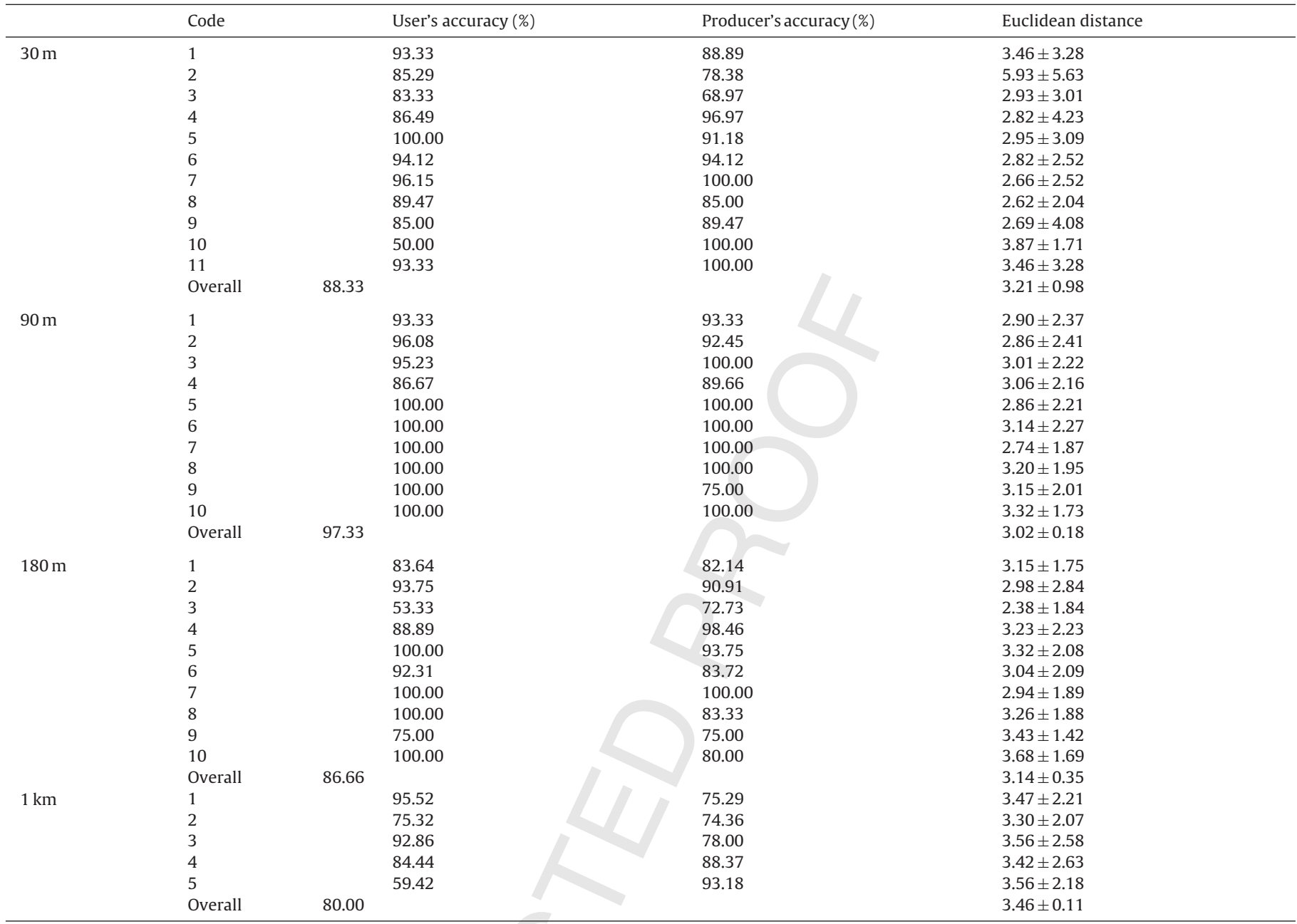

tion and simplification of reality into a limited set of classes (Hou et al., 2013), as well as the existence of spectral interferences, mixed pixels, system errors or conceptual mistakes (Bossard et al., 2000) the possible causes behind this error. Addressing specifically landscape classification process, transferring information from one resolution to other generally involves generalization and loss of accuracy and reliability (Hou et al., 2013). Nevertheless, according to some authors (Ju et al., 2005; Dronova et al., 2012), this transfer of information not always imply a loss of accuracy. In heterogeneous landscapes, such as mountain systems, high local variability might lead to high landscape complexity on the ground and noise in the remote sensing, making class allocation processes difficult and partially erroneous (Kennedy et al., 2009; Rocchini et al., 2013; Nagendra et al., 2013). Therefore, coarsening the spatial resolution of data (from $30 \mathrm{~m}$ to $90 \mathrm{~m}$ ) could help to reduce the perception of this local variability, improving then the accuracy of classification (Ju et al., 2005). Nevertheless, with further coarsening (beyond $90 \mathrm{~m}$ ), boundaries between patches could be poorly represented due to a loss of resolution and distortion in land cover information (Shao and $\mathrm{Wu}, 2008$ ), causing a new error. The loss of the capacity to detect local variability could be also suggested as an explanation of the overall increase of membership probability (and consequent decrease of uncertainty) associated to data coarsening. In this sense, beyond $90 \mathrm{~m}$ spatial resolution, the existence of some classes constituted by rather disparate landscape features resulted in large differences between some pixels and the characteristic vector of the class, increasing uncertainty. Additionally, our study suggested that the use of discrete maps, such as CORINE, in landscape classification might reduce partially confusion, allowing to depict landscape classes with high certainty. It is reasonable to expect that a reduction of mutually-exclusive classes would decrease confusion among classes (i.e., $\mathrm{CI}$ values close to 1) (Strand, 2011). Consistent with this statement, the reduction of classes shearing very similar landscape attributes (classes 8 and 9 were reduced to class 7) when spatial resolution changed from $30 \mathrm{~m}$ to $90 \mathrm{~m}$ could explain the decrease in confusion. On the contrary, at $180 \mathrm{~m}$ resolution, the definition of rather similar classes (like classes 2 and 3 ) implied an increase in confusion. The reduction in the number of classes at $1 \mathrm{~km}$ resolution was probably related to the decrease in $\mathrm{CI}$, due to the lower probability of definition of classes with some degree of overlap. The dependence of $\mathrm{CI}$ on spatial resolution could be related to the modifiable areal unit problem (MAUP), since changes in spatial resolution provided different landscape spatial configuration (Wong, 2009).

Accounting for NDVI-based landscape classifications, we found that the number and typology of landscape classes was only sensitive to change from coarse $(1 \mathrm{~km})$ to middle and high spatial resolution $(180 \mathrm{~m}, 90 \mathrm{~m}$ and $30 \mathrm{~m})$. This lack in classification consistency from $1 \mathrm{~km}$ to the more detailed resolutions could be explained by the role of input variables used in combination with NDVI, especially topography, which is of key relevance to describe landscape in mountain systems. The more detailed information on 
topography and urban influence included in landscape classifications at middle and high spatial resolution, as a consequence of the real change of resolution, let depict regional peculiarities that could not be addressed at $1 \mathrm{~km}$ (Hou et al., 2013). Consequently, the number of classes represented increased. The consistency of NDVI-based landscape classifications across middle and high spatial resolution suggested the adequacy of using spectral indexes, in combination with other variables, in landscape classification processes from a practical point of view. However, the use of NDVI could hamper the description and interpretation of landscape classes, since it informs on biophysical parameters related to vegetation activity, not accounting for land cover directly (Wang and Tenhunen, 2004). Furthermore, some additional considerations should be taken in account concerning the error and uncertainty associated to this data source (Hou et al., 2013). Atmospheric influences and aerosols tend to decrease NDVI values (Carlson and Ripley, 1997) and fluctuations in soil brightness might also lead to large variations in NDVI signal among images (Liu and Huete, 1995). NDVI signal is sensitive to canopy background and could be saturated at high leaf area index (LAI) values (Pettorelli et al., 2005). Looking at the error of NDVI-based landscape classifications, we found that landscape maps developed at $1 \mathrm{~km}$ (the original resolution of NDVI) showed less accuracy than those developed at intermediate resolutions. Maps at the coarsest pixel size might result overly non-specific to be useful (Ju et al., 2005) affecting, therefore, the correct characterization of spatial details of the landscape, due to the vagueness of information (Hou et al., 2013). The decrease in classification accuracy from $90 \mathrm{~m}$ to $30 \mathrm{~m}$ was suggested to be associated with local landscape complexity and variability, making class allocation processes difficult and partially erroneous (Kennedy et al., 2009; Rocchini et al., 2013; Nagendra et al., 2013). Addressing membership probability, the poor influence of spatial resolution change on results might suggest that NDVI index facilitates the definition of homogeneous classes providing accurate pixel allocation, with independence of spatial resolution. Additionally, the increase in confusion among classes at higher spatial resolution than the original one could be associated with both, the increase in the number of classes and the inherent properties of NDVI as a continuous variable. Assumptions for classification methods include that classes are crisp and mutually exclusive, setting boundaries in sites where classes slightly differ (Foody, 2002; Bollinger and Mladenoff, 2005). This might be a problem when working with continuous data in heterogeneous mountain systems, where classes can be inter-grade and co-exist spatially (Foody, 2002; Morán-Ordóñez et al., 2012), resulting in high confusion in regards to which class a pixel should belong (Álvarez-Martínez et al., 2010). This problem would be reduced in more homogeneous systems, where classes are very different and with clear dominance of one of them across space (Bollinger and Mladenoff, 2005).

\section{Table 5}

User's, producer's and overall accuracy of landscape classifications based on topography, urban influence and NDVI (as a proxy of land cover) at different spatial resolutions. The table also shows the probability of membership (i.e., the Euclidian distance from pixel values to the characteristic vector of each class; mean $\pm S D$ ).

\begin{tabular}{|c|c|c|c|c|}
\hline & Code & User's accuracy (\%) & $\begin{array}{l}\text { Producer's } \\
\text { accu- } \\
\text { racy } \\
(\%)\end{array}$ & $\begin{array}{l}\text { Euclidean } \\
\text { dis- } \\
\text { tance }\end{array}$ \\
\hline \multirow[t]{12}{*}{$30 \mathrm{~m}$} & 1 & 96.43 & 65.85 & $2.02 \pm 0.66$ \\
\hline & 2 & 57.14 & 100.00 & $2.14 \pm 0.67$ \\
\hline & 3 & 64.00 & 88.89 & $2.19 \pm 0.54$ \\
\hline & 4 & 87.50 & 63.64 & $2.10 \pm 0.59$ \\
\hline & 5 & 81.25 & 86.67 & $2.13 \pm 0.84$ \\
\hline & 6 & 64.29 & 90.00 & $2.14 \pm 0.52$ \\
\hline & 7 & 88.89 & 100.00 & $2.11 \pm 0.82$ \\
\hline & 8 & 88.00 & 88.00 & $2.05 \pm 0.64$ \\
\hline & 9 & 100.00 & 94.74 & $2.38 \pm 0.61$ \\
\hline & 10 & 83.78 & 65.96 & $2.01 \pm 0.75$ \\
\hline & 11 & 74.51 & 90.48 & $2.02 \pm 0.92$ \\
\hline & Overall & & 79.67 & $2.12 \pm 0.10$ \\
\hline \multirow[t]{12}{*}{$90 \mathrm{~m}$} & 1 & 100.00 & 68.57 & $2.20 \pm 0.58$ \\
\hline & 2 & 72.22 & 100.00 & $2.09 \pm 0.78$ \\
\hline & 3 & 73.33 & 100.00 & $2.12 \pm 0.69$ \\
\hline & 4 & 85.19 & 92.00 & $2.15 \pm 0.61$ \\
\hline & 5 & 83.33 & 100.00 & $2.03 \pm 0.90$ \\
\hline & 6 & 82.22 & 94.87 & $2.14 \pm 0.63$ \\
\hline & 7 & 100.00 & 88.24 & $2.07 \pm 0.96$ \\
\hline & 8 & 100.00 & 95.45 & $2.14 \pm 0.66$ \\
\hline & 9 & 100.00 & 100.00 & $2.12 \pm 0.73$ \\
\hline & 10 & 96.97 & 71.11 & $2.14 \pm 0.64$ \\
\hline & 11 & 87.50 & 97.67 & $2.03 \pm 0.94$ \\
\hline & Overall & & 88.66 & $2.11 \pm 0.05$ \\
\hline \multirow[t]{12}{*}{$180 \mathrm{~m}$} & 1 & 100.00 & 84.00 & $2.08 \pm 0.82$ \\
\hline & 2 & 83.33 & 90.91 & $2.13 \pm 0.67$ \\
\hline & 3 & 77.78 & 82.35 & $2.06 \pm 0.87$ \\
\hline & 4 & 92.16 & 87.04 & $2.15 \pm 0.63$ \\
\hline & 5 & 100.00 & 93.75 & $2.09 \pm 0.80$ \\
\hline & 6 & 93.75 & 97.83 & $2.11 \pm 0.76$ \\
\hline & 7 & 91.67 & 100.00 & $2.07 \pm 0.84$ \\
\hline & 8 & 100.00 & 95.45 & $2.13 \pm 0.68$ \\
\hline & 9 & 100.00 & 100.00 & $2.07 \pm 0.81$ \\
\hline & 10 & 100.00 & 83.33 & $2.14 \pm 0.67$ \\
\hline & 11 & 77.78 & 97.22 & $2.03 \pm 0.93$ \\
\hline & Overall & & 91.33 & $2.10 \pm 0.03$ \\
\hline \multirow[t]{8}{*}{$1 \mathrm{~km}$} & 1 & 83.33 & 83.33 & $1.96 \pm 1.21$ \\
\hline & 2 & 72.73 & 84.21 & $2.08 \pm 0.86$ \\
\hline & 3 & 87.50 & 75.68 & $1.88 \pm 1.13$ \\
\hline & 4 & 86.84 & 80.49 & $2.03 \pm 0.78$ \\
\hline & 5 & 91.43 & 91.43 & $2.15 \pm 0.76$ \\
\hline & 6 & 85.53 & 86.67 & $1.99 \pm 1.00$ \\
\hline & 7 & 93.33 & 95.45 & $1.76 \pm 1.28$ \\
\hline & Overall & & 85.67 & $1.98 \pm 0.13$ \\
\hline
\end{tabular}

Q6 Uncited references

Alves et al. (2014), Bradley and Mustard (2005), Burrough et al. (1997), EEA (2006), Körner (2007), Morán-Ordóñez et al. (2013) and Sepp et al. (1999).

\section{Conclusions}

Remote sensing products informing on land cover, such as the CORINE Land Cover map at $30 \mathrm{~m}$ or the NDVI spectral index from NOAA at $1 \mathrm{~km}$, are valuable tools that, used in combination with other thematic information, allow for producing landscape classifications useful for practical applications. The multi-spatial resolution approach here developed provided a relevant framework for landscape managers, particularly when funding is limited and data source at an appropriated spatial resolution are not available. Efforts should be made to select data at suitable resolutions, matching regional peculiarities and minimizing error and uncertainty in results.

\section{Acknowledgments}

García-Llamas was supported by a predoctoral fellowship from the Ministry of Education of Spain, with reference FPU12/05194. We are grateful to the University of Leon's Mapping Service. Again, we are grateful the Marie Curie project "Monitoring the effects of agricultural landscape change on avian biodiversity using satellite remote sensing" (no UE ENV4-CT98-5130) for his valuable help with NDVI index data. We also thank anonymous reviews for the critical comments on an earlier version of the paper. 


\section{Appendix A. Supplementary data}

Supplementary data associated with this article can be found, in

the online version, at http://dx.doi.org/10.1016/j.jag.2016.03.010.

\section{$491 \quad$ References}

Álvarez-Martínez, J.M., Stoorvogel, J., Suárez-Seoane, S., de Luis Calabuig, E., 2010. Uncertainty analysis as a tool for refining land dynamics modelling on changing landscapes: a case study in a Spanish natural park. Landsc. Ecol. 25 1385-1404

Álvarez-Martínez, J.M., Suárez-Seoane, S., de Luis Calabuig, E., 2011. Modelling the risk of land cover change from environmental and socio-economic drivers in heterogeneous and changing landscapes: the role of uncertainty. Landsc. Urban Plan 101, 108-119.

Álvarez-Martínez, J.M., Suárez-Seoane, S., Palacín, C., Sanz, J., Alonso, J.C., 2015. Can Eltonian processes explain species distributions at large scale? A case study with Great Bustard (Otis tarda). Divers. Distrib. 21, 123-138.

Alves, J., Alves da Silva, A., Soares, A.M.V.M., Fonseca, C., 2014. Spatial and temporal habitat use and selection by red deer: the use of direct and indirect methods. Mamm. Biol. 79, 338-348.

Blasi, C., Carranza, M.L., Frondoni, R., Rosati, L., 2000. Ecosystem classification and mapping: a proposal for Italian landscapes. Appl. Veg. Sci. 3, 233-242.

Bollinger, J., Mladenoff, D.J., 2005. Quantifying spatial classification uncertainties on the historical Wisconsin landscape (USA). Ecography 28, 141-156.

Bossard, M., Feranec, J., Otathel, J., 2000. CORINE Land Cover Technical Guide. Addendum 2000. Technical Report No 40. European Environment Agency, Copenhagen, Available from http://www.eea.europa.eu/publications/ tech40add.

Bradley, B., Mustard, J.F., 2005. Identifying land cover variability distinct from land cover change: cheatgrass in the Great Basin. Remote Sens. Environ. 94, 204-213.

Burrough, P.A., van Gaans, P.F.M., Hootsmans, R., 1997. Continuous classification in soil survey: spatial correlation, confusion and boundaries. Geoderma 77, 115-135.

Carlson, T.N., Ripley, D.A., 1997. On the relation between NDVI, fractional vegetation cover and leaf área index. Remote Sens. Environ. 62, 241-252.

Conese, C., Maselli, F., 1992. Use of error matrices to improve area estimates with maximum-likelihood classification procedures. Remote Sens. Environ. 40 113-124.

Council of Europe, 2000. European Landscape Convention. T- Land, 6, Strasbourg.

Cullotta, S., Barbera, G., 2011. Mapping traditional cultural landscapes in Mediterranean area using a combined multidisciplinary approach: method and application to Mount Etna (Sicily, Italy). Landsc. Urban Plan 100, 98-108.

Di Gregorio, A., Jansen, L.J., 1998. Land Cover Classification System (LCCS): Classification Concepts and User Manual. FAO, Rome.

Di Gregorio, A., Jansen, L.J., 2004. Obtaining land-use information from a remotely sensed land cover map: results from a case study in Lebanon. Int. J. Appl. Earth Obs. Geoinform. 5, 141-157.

Dronova, I., Gong, P., Clinton, N.E., Wang, L., Fu, W., Qi, S., Liu, Y., 2012. Landscape analysis of wetland functional types: the effect of image segmentation scale, vegetation classes and classification methods. Remote Sens. Environ. 127 357-369.

European Centre for Nature Conservation (ECNC), 1997. Action Theme 4: European Landscapes. Draft Action Plan for European Landscapes. ECNC, Tilburg, The Netherlands.

European Environment Agency (EEA), 2007. CLCT 2006 echnical Guidelines. EEA Technical Report No 17. EEA, Copenhagen.

Foody, G.M., Atkinson, P.M. (Eds.), 2002. Uncertainty in Remote Sensing and GIS. Wiley, Chichester.

Foody, G.M., 2000. Mapping land cover from remotely sensed data with a softened feedforward neural network classification. J. Intell. Robot Syst. 29, 433-449.

Foody, G.M., 2002. Status of land cover classification accuracy assessment. Remote Sens. Environ. 80, 185-201.

Gamon, J.A., Huemmrich, K.F., Stone, R.S., Tweedie, C.E., 2013. Spatial and temporal variation of primary productivity (NDVI) of coastal Alaska tundra: decrease vegetation growth following earlier snowmelt. Remote Sens. Environ. 129, $144-153$.

Gan, T.Y., Zunic, F., Kuo, C.C., Strobl, T., 2012. Flood mapping of Danube River at Romania using single and multi-date ERS2-SAR images. Int. J. Appl. Earth Obs. $18,69-81$

Garrigues, S., Allard, D., Baret, F., Weiss, M., 2006. Influence of landscape spatial heterogeneity on the non-linear estimation of leaf area index from moderate spatial resolution remote sensing data. Remote Sens. Environ. 105 (4), 286-298.

Gharadjedaghi, B., Heimann, R., Lenz, K., Martin, C., Pieper, V., Schulz, A., Vahabzeadah, A., Finck, P., Riecken, U., 2004. Verbreitung und Gefährdung Schutzwürdiger Landschaften in Deutschland. Nat. Landsc. 79 (2), 71-81.

Gimona, A., Messager, P., Occhi, M., 2009. CORINE-based landscape indices weakly correlate with plant species richness in a northern European landscape transect. Landsc. Ecol. 24 (1), 53-64.

Hou, Y., Burkhard, B., Müller, F., 2013. Uncertainties in landscape analysis and ecosystem service assessment. J. Environ. Manag. 127, 117-131.
Jelinski, D.E., Wu, J., 1996. The modifiable areal unit problem and implications for landscape ecology. Landsc. Ecol. 11, 129-140.

Ju, J., Gopal, S., Kolaczyk, E.D., 2005. On the choice of spatial and categorical scale in remote sensing land cover classification. Remote Sens. Environ. 96, 62-77.

Körner, C., 2007. The use pf 'altitude' in ecological research. Trends Ecol. Evol. 22, 569-574.

Karl, J.W., Maurer, B.A., 2010. Multivariate correlations between imagery and field measurements across scales: comparing pixel aggregation and image segmentation. Landsc. Ecol. 25, 591-605.

Kennedy, R.E., Townsedn, P.A., Gross, J.E., Cohen, W.B., Bolstand, P., Wang, Y.Q. Adams, P., 2009. Remote sensing change detection tools for natural resource managers: understanding concepts and tradeoffs in the design of landscape monitoring projects. Remote Sens. Environ. 113, 1382-1396.

Kienast, F., Bolliger, J., Potschin, M., de Groot, R.S., Verburg, P.H., Heller, I., Wascher, D., Haines-Young, R., 2009. Assessing landscape functions with broad-scale environmental data: insight gained from a prototype development for Europe. Environ. Manag. 44, 1099-1120.

Lewis, H.G., Brown, M., Tatnall, A.R.L., 2000. Incorporating uncertainty in land cove classification from remote sensing imagery. Adv. Space Res. 26, 1123-1126.

Liu, H., Huete, A., 1995. A feedback based modification of the NDVI to minimize canopy background and atmospheric noise. IEEE Trans. Geosci. Remote Sens. 33 (2), 457-465.

Mücher, C.A., Bunce, R.G.H., Jongman, R.H.G., Klijn, J.A., Koomen, A.J.M., Metzger, M.J., Washer, D.M., 2003. Identification and Characterisation of Environments and Landscapes in Europe Alterra, Rapport 832. Wageningen.

Mücher, C.A., Wascher, D.M., Klijn, J.A., Koomen, A.J.M., Jongman, R.H.G., 2006. A new European Landscape Map as in integrative framework for landscape character assessment. In: Bunce, R.G.H., Jongman, R.H.G. (Eds.), Landscape Ecology in the Mediterranean: Inside and Outside Approaches. European IALE Conference, Faro, Portugal, 29 March-2 April 2005. IALE Publication Series 3, pp. 233-243.

Mücher, C.A., Klijn, J.A., Wascher, D.M., Schaminée, J.H.J., 2010. A new European Landscape Classification (LANMAP): a transparent, flexible and user-oriented methodology to distinguish landscapes. Ecol. Indic. 10, 87-103.

Mata Olmo, R., Sanz Herráiz, C., 2003. Atlas de los paisajes de España. Centro de Publicaciones, Secretarña General Tícnica, Ministerio de Medio Ambiente, Madrid, $682 \mathrm{pp}$.

McCabe, M.F., Wood, E.F., 2006. Scale influences on the remote estimation of evapotranspiration using multiple satellite sensors. Remote Sens. Environ. 105 (4), 271-285.

Morán-Ordóñez, A., Suárez-Seoane, S., Calvo, L., de Luis, E., 2011. Using predictive models as a spatially explicit support tool for managing cultural landscapes. Appl. Geogr. 31, 839-848.

Morán-Ordóñez, A., Suárez-Seoane, S., Elith, J., Calvo, L., de Luis, E., 2012. Satellite Surface reflectance improves habitat distribution mapping: a case study on heath and shrub formations in the Cantabrian Mountains (NW Spain). Divers. Distrib. 18, 588-602.

Morán-Ordóñez, A., Bugter, R., Suárez-Seoane, S., de Luis, E., Calvo, L., 2013. Temporal changes in socio-ecological systems and their impact on ecosystem services at different governance scales: a case study of heathlands. Ecosystems 16 (5), 765-782.

Muniaty, C., Ratshibvumo, T., 2010. Differentiating geological fertility derived vegetation zones in Kruger National Park, South Africa, using Landsat and MODIS imagery. J. Nat. Conserv. 18, 169-179.

Nagendra, H., Lucas, R., Pradinho-Honrado, J., Jongman, H.G., Tarantino, C., Adamo, M., Mairot, P., 2013. Remote sensing for conservation monitoring: assessing protected areas, habitat extent, habitat condition, species diversity and threats. Ecol. Indic. 33, 45-59.

Oke, A.O., Thompson, K.A., 2015. Distribution models for mountain plant species: the value of elevation. Ecol. Model 301, 72-77.

Osborne, P.E., Suárez-Seoane, S., Alonso, J.C., 2007. Behavioural mechanisms that undermine species envelope models: the causes of patchiness in the distribution of great bustards Otis tarda in Spain. Ecography 30, 819-829.

Owen, S.M., MacKenzie, A.R., Bunce, R.G.H., Steward, H.E., Donovan, R.G., Stark, G. Hewitt, C.N., 2006. Urban land classification and its uncertainties using principal component and cluster analyses: a case of study for the UK Wes midlands. Landsc. Urban Plan 78, 311-321.

Paruelo, J.M., Jobbágy, E.G., Sala, O.E., 2001. Current distribution of ecosystem functional types in temperate South America. Ecosystems 4, 683-698.

Pervez, M.S., Budde, M., Rowland, J., 2014. Mapping irrigated areas in Afghanistan over the past decade using MODIS NDVI. Remote Sens. Environ. 149, 155-165.

Pettorelli, N., Vik, J.O., Mysterud, A., Gaillard, J.M., Tucker, C.J., Stenseth, N.C., 2005. Using the satellite-derived NDVI to assess ecological responses to environmental change. Trends Ecol. Evol. 20, 503-510.

Rae, C., Rothley, C., Dragicevic, S., 2007. Implications of error and uncertainty for an environmental planning scenario: a sensitivity analysis of GIS-based variables in a reserve design exercise. Landsc. Urban Plan 79, 210-217.

Regan, H.M., Colyvan, M., Burgman, M.A., 2002. A taxonomy and treatment of uncertainty for ecology and conservation biology. Ecol. Appl. 12 (2), 618-628.

Rivas-Martínez, S., 1987. Memoria del mapa de series de vegetaciín de Espaóa. ministerio de agricultura. In: Pesca y Alimentación. ICONA Serie Tñcnica.

Rocchini, D., Ricotta, C., 2007. Are landscapes as crisp as we may think? Ecol. Model 234, 535-539.

Rocchini, D., Foody, G.M., Nagendra, H., Ricotta, C., Anand, M., He, K.S., Amici, V., Kleinschmit, B., Förster, M., Schmidtlein, S., Feilhauer, H., Ghisla, A., Metz, M.
56

570

572 
G Model

JAG 12261-11

P. García-Llamas et al. / International Journal of Applied Earth Observation and Geoinformation xxx (2016) xxx-xxx

11

653

Neteler, M., 2013. Uncertainty in ecosystem mapping by remote sensing. Compute. Geosci. 50, 128-135.

Roces-Díaz, J.V., Díaz-Varela, A., Álvarez-Álvarez, P., Recondo, C., Díaz-Varela, R., 2015. A multiscale analysis of ecosystem services supply in the NW Iberian Peninsula from a functional perspective. Ecol. Indic. 20, 24-34.

Rouse, J.W., Haas, R.H., Shell, J.A., Bering, D.W., 1973. Monitoring vegetation systems in the great plains with ERTS. In: Proceedings of the Third ERTS Symposium NASA SP-351, 1, U.S. Government Printing Office Washington DC, pp. 309-317.

Schowengerdt, R.A., 1983. Techniques for Image Processing and Classification in Remote Sensing. Academic Press, London.

Schröder, B., Sepplet, R., 2006. Analysis of patterns-process interactions based on landscape models-overview, general concepts, and methodological issues. Ecol. Model 199, 505-516.

Sepp, K., Palang, H., Mander, U., Kaasik, A., 1999. Prospects for nature and landscape protection in Estonia. Landsc. Urban Plan 46, 161-167.

Shao, G., Wu, J., 2008. On the accuracy of landscape patterns analysis using remote sensing data. Landsc. Ecol. 23, 505-511.

Strand, G.H., 2011. Uncertainty in classification and delineation of landscapes: a probabilistic approach to landscape modelling. Environ. Modell. Softw. 26, 1150-1157.

Suárez-Seoane, S., Bawdry, J., 2002. Scale dependence of spatial patterns and cartography on the detection of landscape change: relationships with species perception. Ecography 25 (4), 499-511.

Suárez-Seoane, S., Osborne, P.E., Alonso, J.C., 2002. Large-scale habitat selection by agricultural steppe birds in Spain: identifying species-habitat responses using generalised additive models. J. Apple. Ecol. 39, 755-777.

Tchuenté, A.T.K., De Jong, S.M., Roujean, J.L., Favier, C., Miring, C., 2011. Ecosystem mapping at the African continent scale using a hybrid clustering approach based on 1-km resolution multi-annual data from SPOT/VEGETATION. Remote Sens. Environ. 115, 452-464.

Tomaselli, V., Dimopoulos, P., Marangi, C., Kallimanis, A.S., Adamo, M., Tarantino, C., Panitsa, M., Terzi, M., Veronica, G., Lovergine, F., Nagendra, H., Lucas, R., Mairota, P., Mücher, C.A., Blonda, P., 2013. Translating land cover/land use classifications to habitat taxonomies for landscape monitoring: a Mediterranean assessment. Landsc. Ecol. 28 (5), 905-930.
Tucker, C.J., 1979. Red and photographic infrared linear combinations for monitoring vegetation. Remote Sens. Environ. 8 (2), 127-150.

Council of Europe, United Nations Environment Programme (UNEP), European Centre for Nature Conservation (ECNC) (1996) The Pan-European Biological and Landscape Diversity Strategy. A Vision of Europe's Natural Heritage. ECNC, Tilburg, The Netherlands.

Van Eetvelde, V., Antrop, M., 2008. A stepwise multi-scale landscape typology and characterization for trans-regional integration, applied on the federal state of Belgium. Landsc. Urban Plan 91, 160-170.

Vogiatzakis, I.N., Griffiths, G.H., Melic, M.T., Marine, A., Careddu, M.B., 2006. Landscape Typology in Mediterranean context: a tool for habitat restoration. J. Mediterranean Ecol. 7, 23-30.

Wang, Q., Tenhunen, J.D., 2004. Vegetation mapping with multitemporal NDVI in North Eastern China Transect (NECT). Int. J. Apple. Earth Obs. 6, 17-31.

In: Wascher D.M. (ed) (2005) European Landscape Character Areas-Typologies, Cartography and Indicators for the Assessment of Sustainable Landscapes. Final Project Report as deliverable from the EU's Accompanying Measure project European Landscape Character Assessment Initiative (ELCAI), funded under the Fth Framework Programme on Energy, Environment and Sustainable Development (4.2.2), +150 pp.

Wong, D., 2009. The modifiable areal unit problem (MAUP). In: The SAGE Handbook of Spatial Analysis. SAGE Publications, London, pp. 105-123.

Worboys, G.L., Francis, W.L., Lockwood, M. (Eds.), 2010. A Global Guide. Cronwel Press Group, London, p. 480.

Wu, J., 2004. Effects of changing scale on landscape pattern analysis: scaling relations. Landsc. Ecol. 19, 125-138.

Zhu, X., tiu, D., 2014. Improving forest above ground biomass estimation using seasonal Landsat NDVI time-series. ISPRS J. Photogram. (in press).
688

69

Q8

714
715

Please cite this article in press as: García-Llamas, P., et al., Using remote sensing products to classify landscape. A multi-spatial resolution approach. Int. J. Apple. Earth Observe. Geoinf. (2016), http://dx.doi.org/10.1016/j.jag.2016.03.010 